\title{
Batch drying of sliced tomatoes at specific ambient conditions
}

\author{
Mohammad Jafar Royen ${ }^{1,2}$, Abdul Wasim Noori, ${ }^{1,2}$ Juma Haydary $^{1}$ \\ ${ }^{1}$ Institute of Chemical and Environmental Engineering, Slovak University of Technology in Bratislava, \\ Radlinského 9, 81237 Bratislava, Slovakia, juma.haydary@stuba.sk \\ ${ }^{2}$ Faculty of Chemical Technology, Kabul Polytechnic University, \\ Kart-e Mamoorin, Kabul, Afghanistan, Jafar.royen@kpu.edu.af
}

\begin{abstract}
In this work, drying of tomato slices was studied in a laboratory scale batch dryer working at conditions specific for geographical locations with low ambient pressure and low relative humidity of air. Tomato is a perishable farm product with high moisture content. Despite their high value, tomatoes are subjected to wastage and spoilage during their seasonal period; to last longer after harvested, they need to be treated by drying. Drying is one of the most widely used methods of tomato preserving for a longer period of time. This study involves experimental work on tomatoes drying in a tray laboratory batch dryer with the dimensions of $(490 \times 330 \times 310) \mathrm{mm}$, a load cell-force sensor (range: $0-5 \mathrm{~kg})$, fan (speed: $0-2500 \mathrm{rpm}$ ), air flow sensor $(0-150 \mathrm{l} / \mathrm{min})$ and a temperature and humidity monitoring system. This study was aimed at the development of a suitable drying method for the production of dehydrated agricultural products under specific air properties and climate conditions such as low ambient pressure and low relative humidity. During the experiment, the average ambient pressure was $82 \mathrm{kPa}$, and the average relative humidity of air was $20 \%$. Drying characteristics of tomato slices were determined at three temperature levels, namely: $50{ }^{\circ} \mathrm{C}, 60{ }^{\circ} \mathrm{C}$ and $70^{\circ} \mathrm{C}$,and three air flow rates: $30 \mathrm{l} / \mathrm{s}, 40 \mathrm{l} / \mathrm{s}$ and $50 \mathrm{l} / \mathrm{s}$, for each temperature level. In this study, the effect of temperature, air flow rate, and ambient conditions on the drying rate of tomato slices were studied. The results indicate that during the experiments, tomatoes were dried to the final moisture content of $32.2 \%$ from $92 \%$. Drying time at $50{ }^{\circ} \mathrm{C}, 60^{\circ} \mathrm{C}$ and $70^{\circ} \mathrm{C}$, and air flow of $30 \mathrm{l} / \mathrm{s}$ was $17.80 \mathrm{~h}, 15.80 \mathrm{~h}$, and $14.08 \mathrm{~h}$, respectively. For the air flow rate of $40 \mathrm{l} / \mathrm{s}$, the drying time was $15.0 \mathrm{~h}, 12.9 \mathrm{~h}$ and $11.7 \mathrm{~h}$ and for the air flow rate of $50 \mathrm{l} / \mathrm{s}$, the drying time of tomato slices was $14.0 \mathrm{~h}, 11.6 \mathrm{~h}$ and $10.2 \mathrm{~h}$, respectively.
\end{abstract}

Key words: Batch drying, upland condition, sliced tomatoes, drying temperature, humidity

\section{Introduction}

This study was aimed at the development of a suitable drying method for the production of dehydrated agricultural products in geographical locations with specific climate, such as low ambient pressure and low relative humidity of air. Drying is one of the ancient worldwide used techniques of food preservation, in which dry hot air is normally used to remove water and to inhibit bacteria and microorganisms growth in the processed material. Drying is considered to be a simultaneous heat and mass transfer taking place in the material as well as in its environment (Chkir et al., 2015). Therefore, for further clarification, tomato slices were dried in a laboratory scale batch dryer. Tomato, one of the most scientifically investigated vegetables because of its commercial importance, is highly perishable; and post harvesting losses reach $25 \%$ to $50 \%$. In tropical countries, there is a loss of 20-50 \% from harvesting to consumption (GómezRamírez, et al., 2013). Tomato is a perishable farm product with high moisture content (Bennamoun et al., 2015; Ben Mariem et al., 2014). Despite their high value, tomatoes are subjected to wastage and spoilage during their seasonal period; therefore, after harvested, they have to be treated by drying to last longer. Drying is one of the most widely used methods of tomato preserving allowing longer periods of storage, minimizing packaging requirements and reducing shipping weight. (Gamli, 2011; Movagharnejad et al., 2007; Viswanathan et al., 2003). Tomatoes are the main source of lycopene reducing disease and are used in human diet (Demiray et al., 2013; Durigon et al., 2016; Goula et al., 2008). Also, they are low in calories and rich in vitamins $\mathrm{A}, \mathrm{C}$, and $\mathrm{E}$ and minerals such as calcium, potassium, sodium and phosphorus (Lucini et al., 2017), in total that are ten vitamins and minerals (Correia et al., 2015). Tomatoes are one of the most useful vegetable crops consumed both as fresh or tomato juice, tomato concentrate, ketchup, sauce and canned varieties (Abano et al., 2011). Dried tomatoes are used as a component for pizza and various vegetable and spicy dishes (Doymaz et al., 2014).

For effective drying of tomato slices, air should be hot, dry and moving. Air dryness is referred to climate conditions; the sufficient condition is dry and warm climate with lower relative humidity of air. Climate conditions of Afghanistan where this research has been done are specific and different 
than conditions in many countries where tomatoes drying has already been studied. Afghanistan is an upland country with dry climate and low relative humidity of air as well as lower ambient pressure (around $82 \mathrm{kPa}$ in Kabul). These climate parameters in combination with 300 sunny days per year, enabling use of solar energy, represent excellent conditions for drying to be a very effective method to preserve food products. However, design of a drying process requires the knowledge of drying characteristics of materials at these specific conditions. This work aims to contribute in this area by measurements of drying characteristics of tomato slices.

\section{Materials and Methods}

\section{Sample Preparation}

Tomato is one of the most important vegetable and commercial crops (Kumer et al., 2016). Ripe tomatoes were obtained from a local supermarket in Kabul. They were selected considering size, weight, color, strength, and firmness in order to achieve uniformity in the samples. For experiments, hard red tomatoes with average diameters of $4-6 \mathrm{~cm}$ were selected. The tomatoes were stored in a refrigerator at $0{ }^{\circ} \mathrm{C}$ prior to experiments.

Tomatoes were then washed in distilled water and cut into eighths Slices with uniform triangular cross section (Fig. 2, 3). For each batch, tomato sample with the average mass of $(119 \pm 1) \mathrm{g}$ was used. The initial moisture content was determined in a laboratory moisture analyzer equipped with an analytical moisture balance (capacity 0.001-160 g, VWR, Italy), heater power supply, stainless pan protection with ventilation stopper, keyboard and display monitor, the average initial moisture of sliced tomatoes was found to be $92.03 \%$ (wet basis) as show in Fig. 4.

\section{Experimental Procedure}

Several methods are employed to remove the moisture from food and agriculture products in a variety of industrial applications. In food industry, drying methods include solar, freeze, infrared, microwave and convective drying. Among these methods, convective drying is one of the most popular to be used for dehydration of foods for preservation, transportation and storage purposes (Tzempelikos et al., 2015). Therefore, a batch convective tray laboratory dryer has been used in this study. In this system, the required heat is provided by a hot air stream. Drying process is governed by a number of parameters, including the properties of the food material and external drying conditions such as temperature, velocity of air stream and relative humidity of hot air. Temperature and air flow increase leads to increase of the drying rate. Experiments have been mainly used to assess the drying rate and total time needed for the removal of moisture from sliced tomatoes to reach the equilibrium point at the conditions applied.

A tray laboratory batch dryer shown in (Fig. 1) was employed in drying of tomato slices. The unit basi-

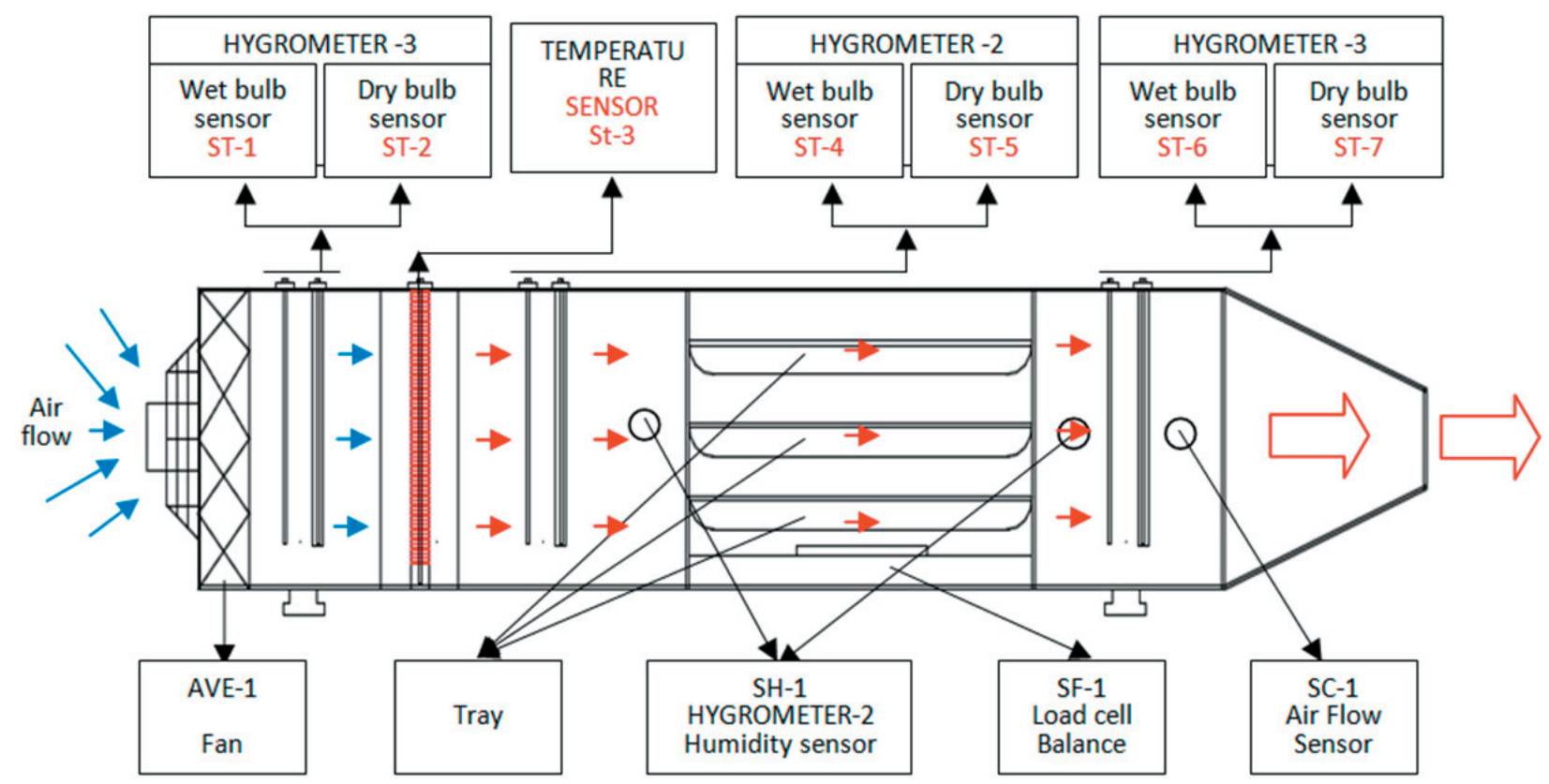

Fig. 1. Scheme of the laboratory batch tray dryer: ST-1, ST-2 dry \& wet bulb temperature sensors at the beginning, ST-4, ST-5 dry \& wet bulb temperature sensors after heating, ST-6,

ST-7 dry \& wet bulb temperature sensors at the end, ST-3- heating element temperature sensor. 
cally includes: a stainless steel tunnel with the dimensions of $(2000 \times 450 \times 400) \mathrm{mm}$, length, height and width respectively, axial fan with angular frequency of $0-2500 \mathrm{rpm}$, air flow sensor $(0-150 \mathrm{l} / \mathrm{min})$, load cell-force sensor (range: $0-5 \mathrm{~kg}$ ) with continuous weight balance, heating elements $(3 \mathrm{~kW})$, control system, four drying trays, temperature and pressure sensors. The drying chamber walls were made of a stainless steel layer on the inside, aluminum on the outside, and expanded polystyrene plates between the metal layers to minimize the heat transfer through the chamber walls.

The axial-flow fan is located at the entrance of the drying tunnel. It introduces ambient air (humidified air if required) into the tunnel. The speed of the air introduced can be measured using a sensor located inside the chamber. Heating elements, which are placed next to the fan, heat the air and control the temperature. The unit has three strategically located hygrometers to ensure the optimum humidity and temperature required for the drying process. These hygrometers consist of two temperature sensors, one of them wrapped in an absorbing cover (wet bulb) and the other directly located in the tunnel (dry bulb); their performance, together with a psychrometric chart, allows determining the degree of humidity, enthalpy, etc. (Edibon, 2014).

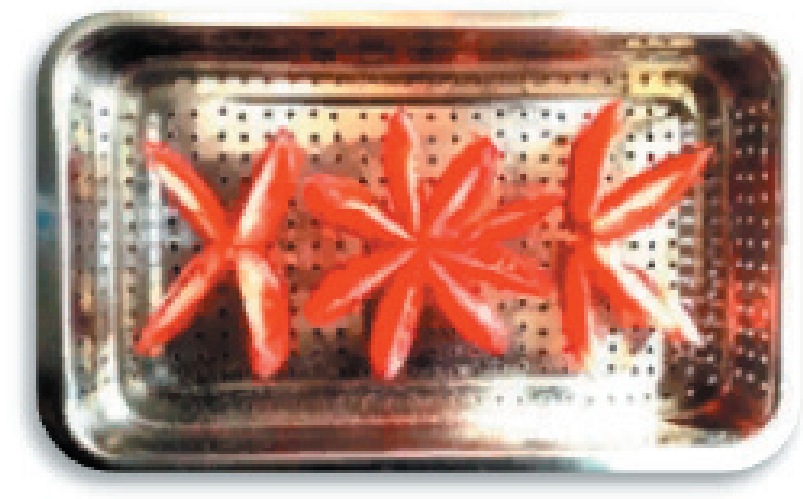

Fig. 2. Tomato sliced sample before drying.

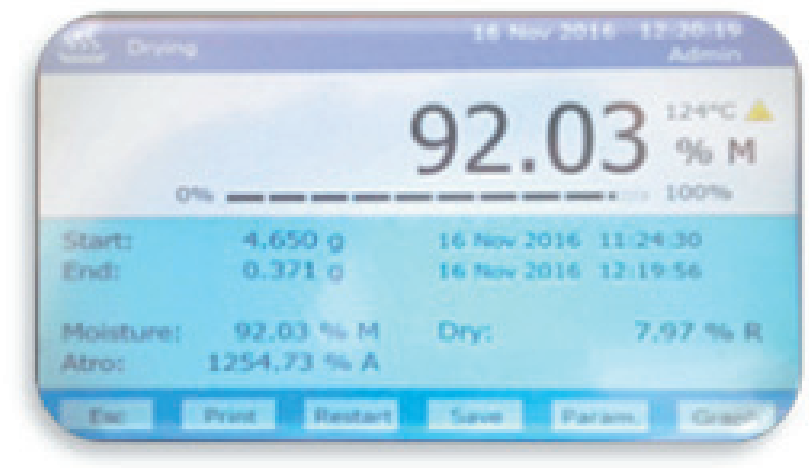

Tomato samples were cut and spread uniformly on a perforated tray placed inside the drying chamber (Fig. 2 and Fig. 3) The dryer was first run without the sample for about $10 \mathrm{~min}$ to $15 \mathrm{~min}$ to set the desired conditions before each drying experiment. The drying process started when the optimum drying conditions were achieved. Trays with the tomato samples were placed inside the tunnel of the dryer in their designated positions and the measurement started from this point. Sample weight loss was recorded at 5 min intervals.

Moisture loss was determined by periodic measurement of the sample weight during the drying process, which was recorded at $5 \mathrm{~min}$ intervals by means of a digital balance connected to a computer to ensure data acquisition.

During the process, drying was carried out to the final moisture content of $32.2 \%$ from the initial moisture content of about 92.03 \% (w.b.). The experiment was carried out under average ambient pressure of $82 \mathrm{kPa}$, average relative humidity of air of $20 \%$ and ambient temperature of $15-18^{\circ} \mathrm{C}$. Drying characteristics of tomato slices were determined at three temperature levels: $50{ }^{\circ} \mathrm{C}, 60^{\circ} \mathrm{C}$ and $70{ }^{\circ} \mathrm{C}$, and three air flow rates: $30 \mathrm{l} / \mathrm{s}, 40 \mathrm{l} / \mathrm{s}$ and $50 \mathrm{l} / \mathrm{s}$, for each temperature level.

Drying is an energy intensive process that results in the removal of moisture from solid samples

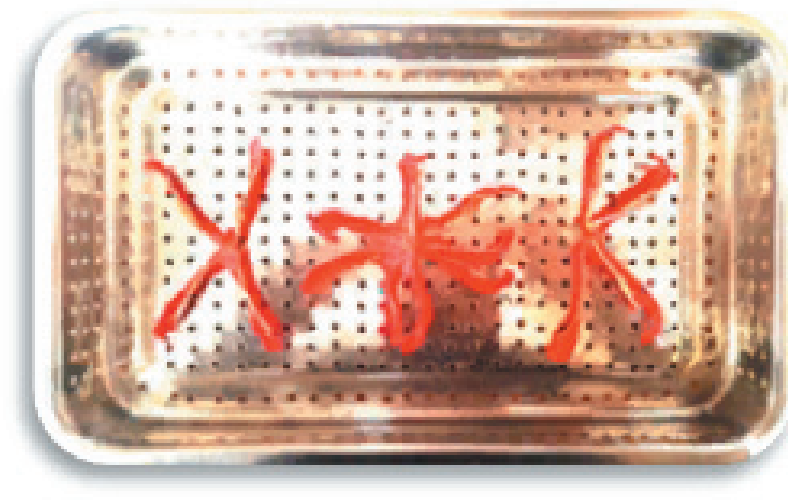

Fig. 3. Tomato sliced sample after drying.

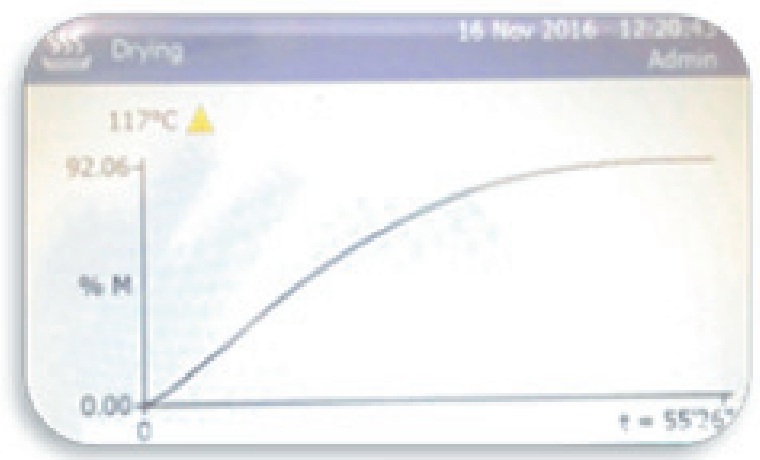

Fig. 4. Total moisture content of tomatoes (\% M). 
by evaporation. Normally, the drying process is optimized to utilize minimum amount of energy to evaporate maximum moisture content from the samples. It means that by increasing the drying temperature, the drying rate increases and the drying time decreases. However, an increase of the drying temperature leads to the loss of the organoleptic properties (texture, color, density and adsorption characteristics) as well as nutritional value (vitamins, minerals, proteins, carbohydrates, dietary fiber) (Khama et al., 2016). Therefore, the drying temperature from the interval of $50-70{ }^{\circ} \mathrm{C}$ was selected. In this study, the effect of temperature and air flow rate at specific ambient conditions such as lower pressure and air humidity on the drying rate of tomato slices was studied.

\section{Results and Discussion}

The obtained results indicate that during the experiment, $95.87 \%$ of water from the tomatoes evaporated. The drying time at the temperature of $50{ }^{\circ} \mathrm{C}$, $60{ }^{\circ} \mathrm{C}$ and $70^{\circ} \mathrm{C}$, and air flow of $30 \mathrm{l} / \mathrm{s}$ was $17.80 \mathrm{~h}$, $15.80 \mathrm{~h}$, and $14.08 \mathrm{~h}$, respectively. For the air flow rate of $40 \mathrm{l} / \mathrm{s}$, the drying time was $15.0 \mathrm{~h}, 12.9 \mathrm{~h}$ and $11.7 \mathrm{~h}$ and for the air flow rate of $50 \mathrm{l} / \mathrm{s}$ it was $14.0 \mathrm{~h}$, $11.6 \mathrm{~h}$ and $10.2 \mathrm{~h}$, respectively. Table 1 shows the time required to reach equilibrium at air flow rates and temperatures applied in the experiments.

Drying process of tomato slices was continued until the product achieved its final mass indicated by the stabilization of the value recorded by the balance. Data analysis was performed using experimental data for the moisture ratio $(M R)$ by the following equation (Akanbi et al., (2006); Belghith et al., 2016; Ruiz Celma et al., 2009; Sacilik et al., 2006):
Tab. 1. Effect of air temperature and flow rate on the drying time.

\begin{tabular}{cccc}
\hline No. & $\begin{array}{c}\text { Air flow rate } \\
(\mathrm{l} / \mathrm{s})\end{array}$ & $\begin{array}{c}\text { Temperature } \\
\left({ }^{\circ} \mathrm{C}\right)\end{array}$ & $\begin{array}{c}\text { Drying time } \\
(\mathrm{h})\end{array}$ \\
\hline 1 & 30 & 50 & 17.80 \\
2 & 30 & 60 & 15.80 \\
3 & 30 & 70 & 14.08 \\
4 & 40 & 50 & 15.00 \\
5 & 40 & 60 & 12.90 \\
6 & 40 & 70 & 11.70 \\
7 & 50 & 50 & 14.00 \\
8 & 50 & 60 & 11.60 \\
9 & 50 & 70 & 10.20 \\
\hline
\end{tabular}

$$
M R=\frac{\left(X_{t}-X_{e q}\right)}{\left(X_{0}-X_{e q}\right)}
$$

Where $X_{t}$ is the moisture content dry basis at any time ( $\mathrm{kg}$ water $/ \mathrm{kg}$ dry solid), $X_{0}$ is the initial moisture content dry basis ( $\mathrm{kg}$ water/ $\mathrm{kg}$ dry solid), and $X_{e q}$ is the equilibrium moisture content dry basis of the sample ( $\mathrm{kg}$ water/ $\mathrm{kg}$ dry solid). The moisture ratio $(M R)$ versus the drying time for a selected value of final moisture content dry basis of the product $(0.322 \mathrm{~kg}$ moisture $/ \mathrm{kg}$ of wet solid $)$ is shows in Fig. 5.

Fig. 6 shows the relative content of water in the wet material, the relative moisture curves according to drying time $(X=f($ Time $))$ were obtained for three investigated temperatures of $50{ }^{\circ} \mathrm{C}, 60^{\circ} \mathrm{C}$ and $70^{\circ} \mathrm{C}$ and three air flow rates of $30 \mathrm{l} / \mathrm{s}, 40 \mathrm{l} / \mathrm{s}$ and $50 \mathrm{l} / \mathrm{s}$. During the initial stages of drying, rapid moisture removal from the product was observed, which later decreased with the increasing drying time.

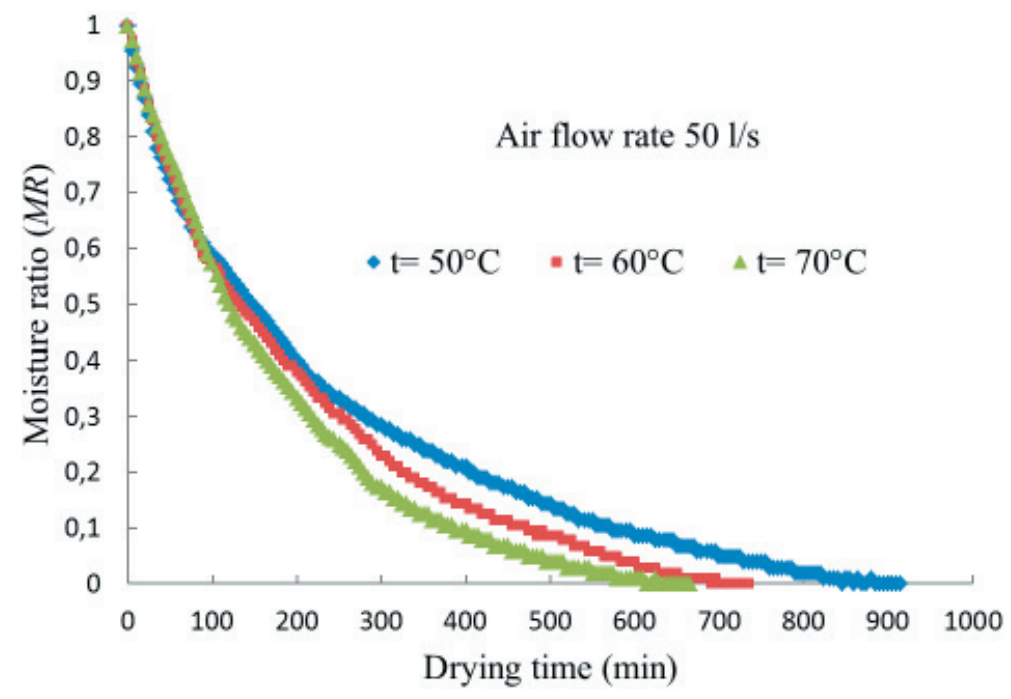

Fig. 5. Change in the moisture ratio $(M R)$ over time at the $50 \mathrm{l} / \mathrm{s}$ air flow rate and different temperatures. 


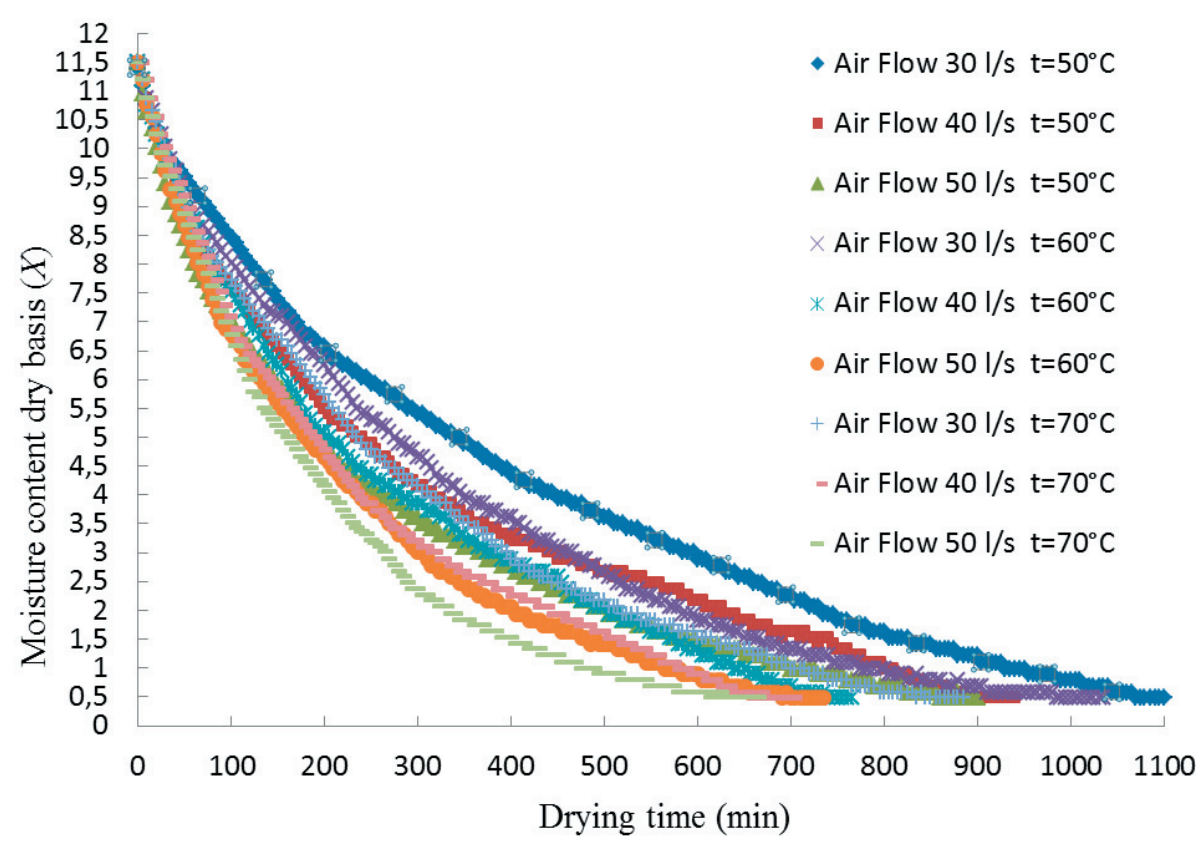

Fig. 6. Variation of the relative moisture content of tomato samples with the drying time for different temperatures and drying air flow rates.

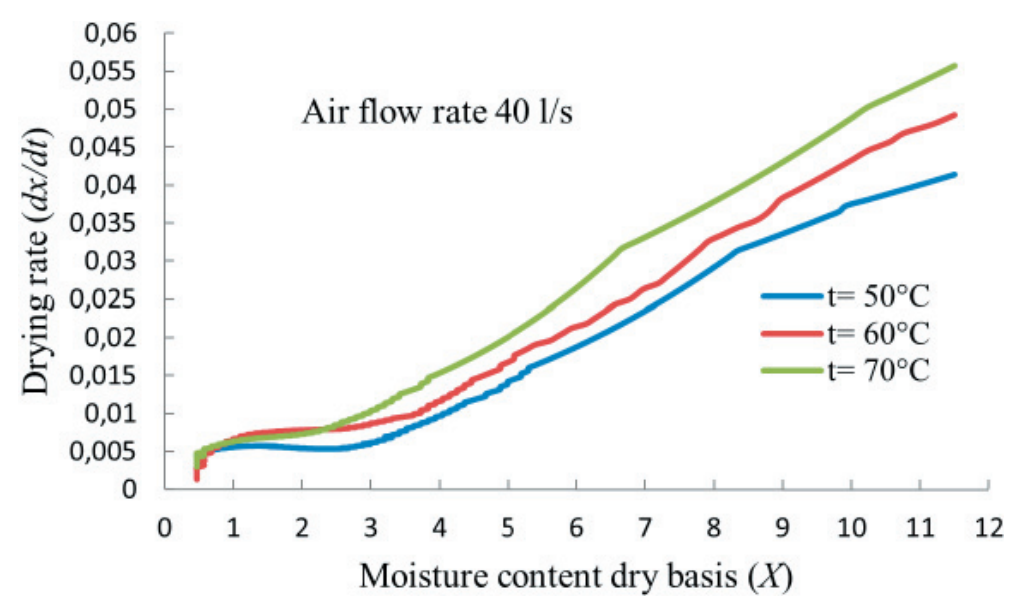

Fig. 7. Drying rate versus relative moisture content.

$$
X=\frac{m_{\mathrm{H}_{2} \mathrm{O}}}{m_{d r y}}=\frac{m_{w e t}-m_{d r y}}{m_{d r y}}
$$

Where: $m_{\text {wet }}$ is the mass of wet solid and $m_{d r y}$ is the mass of dry solid (Haydary and Steltenpohl, 2015). Drying rate curves of the samples as a function of the moisture content dry basis for different drying temperatures $\left(50^{\circ} \mathrm{C}, 60^{\circ} \mathrm{C}\right.$ and $\left.70{ }^{\circ} \mathrm{C}\right)$ and constant air flow rate were determined considering the moisture content dry basis $(d X / d t=f(X))$ and the drying time $(d X / d t=f(t))$ (Khama et al., 2016) presented in Fig. 7 and Fig. 8, respectively. Drying curves were obtained by regression of experimental data using a forth degree polynomial trend curve and its subsequent derivation.

The drying curves show that the drying rate decreased with the decreasing moisture content dry basis of tomato slices (Fig. 8). It also decreased with the increasing temperature (Fig. 9). The drying rate also depends on the diffusion of moisture from inside of the sample to its environment. Thus, the whole drying process proceeds in the falling rate period which indicates that diffusion is the most likely physical mechanism governing the moisture movement in tomato slices (Doymaz, 2007). Usually, the drying process takes place in two successive phases; in the first phase, free water is evaporated from the surface of the material at constant drying rate; the second phase is characterized by diffusion of the moisture to the sample surface when the drying rate decreases. Despite the high tomato moisture content, the first drying phase with constant drying rate was not clearly visible.

The effect of drying temperature on the drying time at the same equilibrium moisture content at different air flow rates is shown in Fig. 9. 


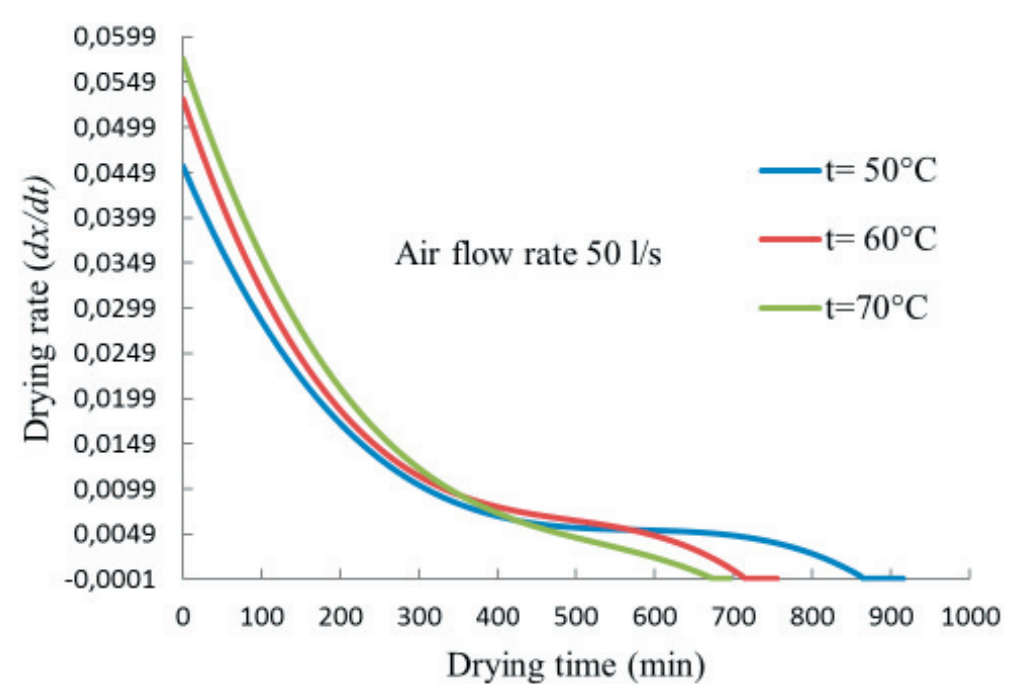

Fig. 8. Drying rate versus drying time.

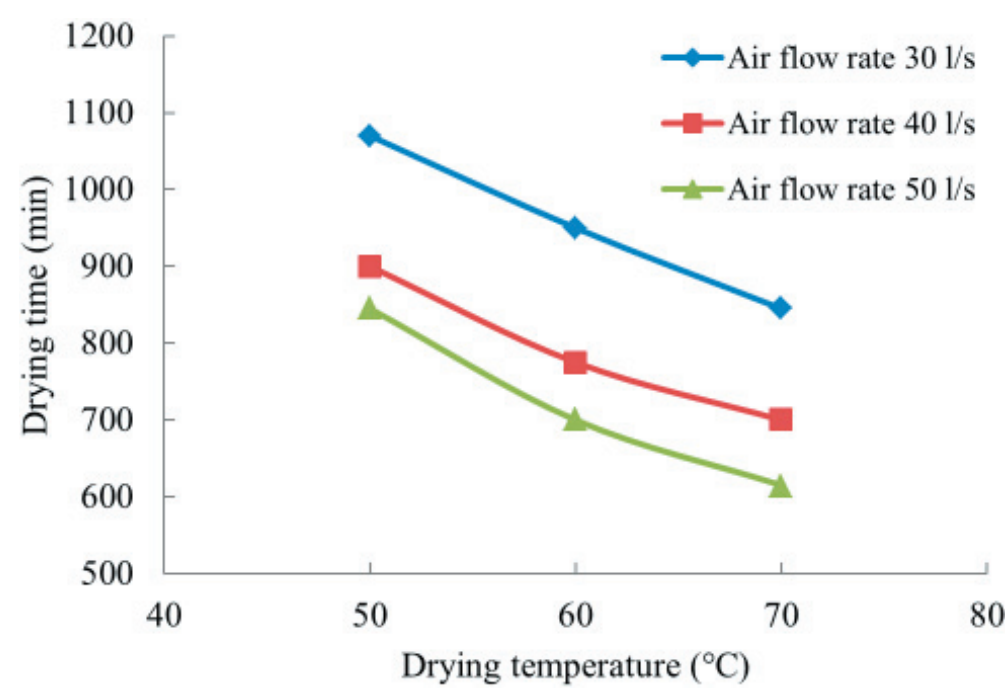

Fig. 9. Drying time required for reaching the moisture content of $32.2 \%$ at different temperatures and air flow rates.

The initial moisture content of tomato slices was $92.03 \mathrm{~g}$ per $100 \mathrm{~g}$ of fresh tomato. Drying processes were stopped when $95.9 \%$ of the total initial moisture of the samples was removed. Drying time decreased when air flow rate increased from $30 \mathrm{l} / \mathrm{s}$ to $50 \mathrm{l} / \mathrm{s}$. Both, temperature and air flow rate have significant effect on the drying time as indicated in Table 1. However, as shown in Fig. 9, the effect of temperature at lower air flow rates is more significant than at higher flow rates.

\section{Conclusions}

In this study, drying of tomato slices was experimentally studied employing various temperatures and air flow rates to achieve evaporation of around $95.9 \%$ of initial water. The results confirm the positive effect of temperature and air flow rate on the drying rate. Drying air temperature has an essential role in the cha- racterization of drying behavior of tomato samples. By increasing the temperature and flow rate of the drying air, the drying potential increases and consequently the drying time and drying rate decrease. In this study, tomato slices were dried at temperature values: $50^{\circ} \mathrm{C}, 60^{\circ} \mathrm{C}$ and $70^{\circ} \mathrm{C}$, and three air flow rates: $30 \mathrm{l} / \mathrm{s}, 40 \mathrm{l} / \mathrm{s}$ and $50 \mathrm{l} / \mathrm{s}$, for each temperature. Faster tomato slices drying was achieved at the temperature of $70^{\circ} \mathrm{C}$ and the air flow rate of $50 \mathrm{l} / \mathrm{s}$, at the average ambient pressure between $80 \mathrm{kPa}$ and $82 \mathrm{kPa}$, low average relative humidity of air between $20 \%$ and $21 \%$ and ambient temperature of $17{ }^{\circ} \mathrm{C}$ and $18{ }^{\circ} \mathrm{C}$. However, higher temperature leads to higher energy consumption for the drying process.

\section{Acknowledgement}

This work was supported by the project SAMRS/2016/ AFG/01/01 of the Slovak Agency for International Development Cooperation and the Grant APVV-15- 
0148 provided by the Slovak Research and Development Agency.

\section{Reference}

Abano E, HMa, Qu W (2011) Journal of Food Processing and Technology 2: 123. doi: 10.4172/21577110.1000123.

Akanbi TC, Adeyemi SR, Ojo A (2006) Journal of Food Engineering 73: 157-163.

Belghith A, Azzouz S, ElCafsi A (2016) Heat Mass Transf. Springer-Verlag Berlin Heidelberg 52: 407-419.

Bennamoun L, Khama R, Léonard A (2015) Food and bioproducts processing 94: 114-123.

Ben MS, Ben MS (2014) International Journal of Energy Engineering. 4 (2A): 17-24.

Chkir I, Amine BM, Ayed L, Azzouz S, Kechaou N, Hamdi M (2015) Food and bioproducts processing. 94: $10-19$.

Correia AFK, Loro AC, Zanatta S, Spoto MHF, Vieira TMFS (2015) Hindawi Publishing Corporation International Journal of Food Science Volume 2015, Article ID 970724, 7 pages.

Demiray E, Tulek Y, Yilmaz Y (2013) LWT - Food Science and Technology 50: 172-176.

Doymaz I, Ozdemir O (2014) International Journal of Food Science and Technology 49: 558-564.

Doymaz B (2007) Journal of Food Engineering 78: 1291-1297.

Durigon A, Gimenez de Souza P, Augusto M, Carciofi B, Borges L, João (2016) Food and bioproducts processing 100: $145-155$.
Edibon (2014) C/Del Agua, 14. P.I. San Jose de Baleras. 28918 LEGANES (Madrid) SPAIN.

Goula AM, Karapantsios TD, Achilias DS, Adamopoulos KG (2008) Journal of Food Engineering 85: 73-83.

Gómez-Ramírez C, Sosa-Morales ME， Palou E, López-Malo A (2013) International Journal of Food Microbiology 164: 23-25.

Haydary J, Steltenpohl P (2015) Chemical Engineering II, Vol. 1 (pp 180-194). Ministry of higher education of Afghanistan, Bratislava, Slovakia, STU.

Khama R, Aissani F, Alkama R, Bennamoun L, Fraikin L, Salmon T, Plougonven E, Leonard A (2016) Journal of Engineering Science and Technology 3: 443-457.

Kumer S, Akanda MAR, Biswas DK, Roy A, Khatun MA, Goffar SK (2016) Journal of Integrative Agriculture 15: 2380-2392.

Lucini L, Rocchetti G, Kane D, Trevisan M (2017) Food Control 73: 696-703.

Movagharnejad K, Maryam N (2007) Computers and Electronics in Agriculture 59: 78-85.

Ruiz CA, Cuadros F, López-Rodríguez F (2009) food and bioproducts processing 87: 282-291.

Sacilik K, Keskin R, Konuralp EA (2006) Journal of Food Engineering 73: 231-238.

Tzempelikos DA, Mitrakos D, Vouros AP, Bardakas AV, Filios AE, Margaris DP (2015) Journal of Food Engineering 156: 10-21.

Viswanathan R, Jayas DS, Hulasare RB (2003) Biosystems Engineering 86:465-472. 